\title{
The Analysis of Credit Rating Institutions in Financial Crisis
}

\author{
Pan Xiaodie ${ }^{1 *}$, Lu Cai ${ }^{2}$ \\ ${ }^{1}$ Department of Public Administration, Nan fang College of Sun Yat-sen University, Guangzhou, Guangdong, \\ 510000, China \\ ${ }^{2}$ Department of Public Administration, Nan fang College of Sun Yat-sen University, Guangzhou, Guangdong, \\ 510000, China \\ *Corresponding author's e-mail: 562849196@qq.com.
}

\begin{abstract}
This paper mainly describes the function of credit rating agencies and their impact on the capital market, as well as the role of credit rating agencies in the financial crisis. This paper makes a series of investigations on the failure of credit rating agencies to make full use of the early warning function of credit rating, and puts forward three problems of credit rating agencies, including improper handling of conflicts of interest in rating business, poor rating quality, and lack of transparency in the operation of credit rating agencies. The lack of transparency in the internal process and content of rating, the lack of comparable data between the rating of undifferentiated structured goods and traditional goods, and the lack of comparable data on the operation performance of credit rating agencies are the reasons for the lack of transparency in the operation of credit rating agencies, as well as the important reasons for the financial storm.
\end{abstract}

Keywords: credit rating agency, financial crisis, grading

\section{FUNCTION OF CREDIT RATING AGENCY}

Credit rating agency (CRA) plays an important role in the global financial market. The credit rating opinions issued by them help to reduce the information asymmetry between bond issuers and investors. Therefore, credit rating agencies always provide independent, objective and high-quality credit rating. Credit rating agencies are independent credit opinion providers recognized by the market. In the past, the main business of credit rating agencies [1] was to provide analysis and opinions on the possibility of default or expected loss of the company and sovereign risk. In recent years, these credit rating agencies have begun to provide a wide range of ratings for complex financial instruments, such as structured financial products.[2] Credit rating agencies play an important role in the financial market. Investors, creditors, issuers and the government think highly of their credit rating activities. Investors regard the results of credit evaluation as important information of investment decisions and as the basis of whether they are willing to bear risks. The evaluation results of issuers and securities will affect the cost of issuing securities or capital increase. The continuous deterioration of the debtor's credit rating will face the need to perform special contractual obligations, for example, when the credit situation deteriorates to a certain extent, it will become the reason for immediate repayment of loans. Finally, on credit rating in financial regulation: the most obvious example is the EU's capital requirements Direct. Under the requirements of the directive, banks are authorized to use credit rating as a reference indicator to calculate whether they have sufficient capacity to pay. In the New Basel Capital Agreement, it is allowed to determine their credit risk level through the credit rating of external credit rating agencies, which is known as the standardized approach. [3]

\section{THE ROLE OF CREDIT RATING AGENCIES IN THE FINANCIAL CRISIS}

Since August 2007, the world's financial markets have experienced an unprecedented crisis of confidence. The crisis stemmed from subprime mortgages in the United States and then spread to the entire financial market. This financial storm is a complex phenomenon formed by many reasons. Subprime mortgages allow buyers with poor credit to buy (and therefore have a high risk of debt default) and have a looser standard of review. Many of these subprime mortgages are combined in asset pools and become new financial instruments (structured goods) sold in the world through the process of securitization. These financial instruments are often recombined through another complex financial innovation and sold to investors like banks, investment funds, retirement funds, insurance companies, or other professionals. More than $80 \%$ of these secondary structured goods are rated at the highest level by credit rating agencies. The storm hit Europe hard in three ways. First of all, some European financial institutions face losses due to their exposure to the US secondary market, such as US subprime mortgage securities held through SPV.

Second, the financial problems have seriously slowed down the economic growth expectations of the United States. [4] Because of the interconnection of Global trade, 
it affects the economic development of Europe. Finally, uncertainty in the global market has eroded the price of European assets and reduced consumer and business confidence. Credit rating agencies are very close to the source of the problems caused by the subprime mortgage. They give high praise to those financial products and think they are worthy of investment. Investors trust the professional knowledge of credit rating agencies, but they are not concerned about the risk characteristics of these financial instruments, the performance of basic assets and the general market view. In the first quarter of 2008, more than six trillion euros of securitized goods in the United States were not yet due, while in Europe, about one trillion and two hundred billion euros were not yet due. $75 \%$ of these structural goods have obtained the highest grade 6 rating from credit rating agencies. The vast majority of investors are not familiar with structured goods, trying to get higher returns from the structured goods market. However, the structural commodities with the highest rating have more profits than the government bonds or corporate bonds of the same level, which naturally become the hot commodities in the market. However, the AAA

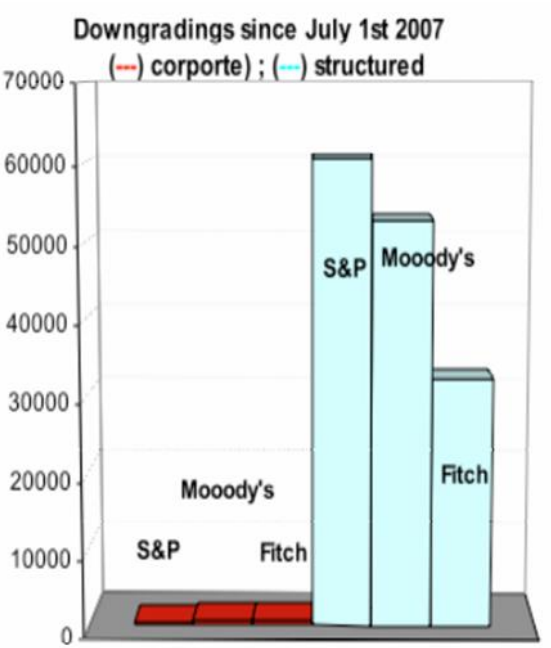

rating of the structural commodities is different from the AAA rating of the government bonds. Although the credit rating agencies know it, the investors are often confused. In the face of a bad market view, investors' confidence in sub structured commodities has been shaken, and internal reevaluation requirements have responded. Credit rating agencies have decided to downgrade these financial instruments on a large scale. It can be seen from Figure 1 that in the downgraded part, from July 1, 2007 to June 24, 2008 , credit rating agencies lowered the rating of 145899 structural goods, compared with only 1 , During this period, 445 enterprise ratings were lowered, while the adjustment rate of upgraded structural goods was much higher than that of traditional ratings, and the difference with the reduction was that the number of upgrades was much lower. Therefore, compared with the traditional rating [5] business (enterprise rating, sovereign rating), credit rating agencies make a serious and systematic wrong rating of structured financial products. Therefore, this problem has already had a very serious impact on the structural financial sector.

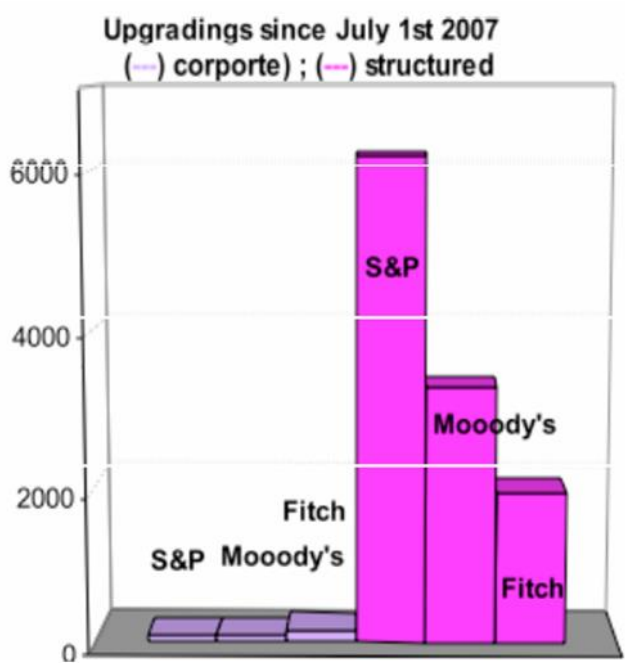

Figure 1 Stop adjustment of structural commodity rating and enterprise rating by three major credit rating agencies in the United States (start date: July 2007)

As the credit rating agencies downgrade the securitized commodities substantially, it has the effect of boosting the collapse of market confidence. This substantial downgrade also implies that the goods evaluated by the current model can reach the rating standard at the time of issuance or the evaluation of the possibility of default is not accurate. The disaster brought by the subprime mortgage proves that the current management system of credit rating agencies needs to be greatly improved.

\section{THE CAUSES OF CREDIT RATING AGENCIES' FINANCIAL CRISIS}

First, the internal process and content of rating are lack of transparency, credit rating agencies fail to provide sufficient information on the characteristics and limitations of structural commodity rating, and the information on rating models and key assumptions used in the production of rating is also insufficient. The transparency of these internal processes and ratings hinders market participants' understanding of the importance of ratings.

Second, there is no distinction between the rating of structured goods and traditional goods. Credit rating agencies use the same rating category for structured goods and traditional goods. Many investors are not familiar with securitized products, and they have little knowledge of the risk characteristics of the products. It is easy to compare traditional bonds and make judgments based on the same rating category. Many investors are sure that the structural products (e.g. CDOs) rated by AAA are as safe as government bonds. As for credit rating agencies, most of them are reluctant to consider individual rating intervals for different asset classes. They say that the possibility of 
default of various commodities can be compared with each other across different types of assets, even though the market characteristics of various financial instruments are quite different. Recently, however, some credit rating agencies have begun to seek opinions from market participants on whether to use special symbols for different asset classes. A survey from CFA society asked its members (professional investors) the following questions: "do you think credit rating agencies should be forced to use different rating symbols for structured goods?" Of the 1956 responses, 47\% responded "yes", $42 \%$ responded "no", and $11 \%$ responded "No comments". It can be seen that even among the professional investors, nearly half of them think that the rating of structured goods should be different from the traditional rating. The reason is that the two ratings have different meanings. If the same symbols are used, it is easy to cause misunderstanding.

Third, there is a lack of comparable data on the operational performance of credit rating agencies. Occasionally, credit rating agencies will provide users with research reports on rating conversion or default to track and analyze the rating activities of bonds in a certain period. These reports usually include comments on upgrades / downgrades and defaults. These reports are the potential basis for assessing the accuracy of credit rating agencies' judgments over the years. Therefore, there are two problems. First, market participants point out that the references in these reports may not be complete. Second, there are different ways for credit rating agencies to collect data and present it publicly.

\section{CONCLUSION}

The financial storm highlighted the regulatory problems of credit rating agencies. In the past, EU regulations only used indirect regulations to match self regulatory regulations, which has been considered unable to effectively deal with the problem of credit rating agencies. Therefore, EU decided to regulate credit rating agencies in a unified way through legislation in the form of "Regulations". The specific content of the specification can be divided into several parts. The scope of disclosure includes the main analyst information responsible for making the rating, important rating methods and assumptions and other relevant information, the nature and limitations of the rating. For structural goods, the credit rating agency should additionally disclose the information of loss and cash flow analysis, and pay attention to the basic assets of structural goods to a certain extent, and the difference with other types of rating shall be explained. As far as the frequency of disclosure is concerned, conflicts of interest, definitions of attached businesses, policies for issuing ratings, salary arrangement policies, and changes in rating methods should be disclosed continuously; data on default rates of various rating categories over the years, whether these types of default rates have been updated, and the list of top 20 principals whose sources of income should be disclosed regularly; in addition, in order to rebuild public confidence in the credit rating industry, credit rating agencies issue transparency reports every year. At the same time, to make investors compare the performance of credit rating agencies, we need to establish a rating database. China's credit rating system started late, and there are many links between China's financial regulations and credit rating. It's worth noting. I hope that through this rough explanation, in addition to a general understanding of the transparency of credit rating agencies, I can also have a further understanding of how the EU deals with the relevant issues of credit rating agencies.

\section{REFERENCES}

[1] J.Kim, L.Z.Ma, H.P.Wang, Financial development and the cost of equity capital. Evidence from China, China Journal of Accounting Research. 8(04) (2015), pp. 243-277.

[2]Z.R.Wang, E.R.Liu, Complexity of structured financial products, cognitive bias of investors and purchase intention, Financial theory and practice. (01) (2019), pp. 9-16.

[3]C.Y.Lim, O.Y.Kevin, Regulatory pressure and income smoothing by banks in response to anticipated changes to the Basel II Accordq, China Journal of Accounting Research. 10(01) (2017), pp. 9-32.

[4] T.Schenbaum, Global financial crisis and its impact on World Trade and world economy, Chinese law, (03) (2010), pp. 27-38+87-95.

[5] M.T..Xu International regulation reform of credit rating and construction of China's credit rating legislation, Suzhou University, 2010. 